\title{
The Concept of Early Childhood Science Learning
}

\author{
Febru Puji Astuti ${ }^{1}$, Naura Nazhifa ${ }^{2}$, Afaf Azizah $^{3}$ \\ \{februpuji@ummgl.ac.id $\left.{ }^{1}\right\}$ \\ Early Childhood Education Department, Universitas Muhammadiyah Magelang, Indonesia ${ }^{1,2,3}$
}

\begin{abstract}
This study aims to determine the appropriate science learning concept for early childhood based on the results of a literature review. Literature review research refers to the relevant study research results on the early childhood science learning topic. The results showed that there were several things related to early childhood science learning. Namely: (1) teacher competence in the science learning process, (2) basic concepts of early childhood science learning, (3) science learning program, (4) science learning process in early childhood.
\end{abstract}

Keywords: Science; early childhood; learning concepts

\section{Introduction}

Each individual brings different uniqueness, interests, aptitude, and competence. The variety of experiences, stimulation, opportunities provided by the environment has a substantial influence on the formation of a curiosity [1]. As a child growing up, curiosity will grow more widely following their growing social environment. Educational institutions become a place for every child to hone their interests, aptitude, knowledge through more structured activities. The early childhood learning process ideally includes both academic development abilities, cognitive, language, social, emotional, physical, and motor development. However, in fact, until now, learning mainly at the kindergarten level, is still centered on improving academic ability. There is a tendency for learning to take place in a teacher center and assume that teachers understand many things while children do not have any knowledge. This learning method can be detrimental to children because it contradicts the principles of acquisition of knowledge that occurs through exploration and play activities.

Curiosity promotes a child to investigate the surroundings and build new understandings. Children gain knowledge by gathering information through the surrounding environment, through events that are seen or experienced by themselves. By playing, allows children to acquire something new through fun things and allowed them to develop optimally build upon the interests and the child's talents [2]. Children learn many ideas through concreted firsthand experience and are simultaneously building knowledge and other development aspects of themselves [3].

Science learning is an applicative learning process of obtaining knowledge that takes place through direct interaction between individuals and the environment that aims to find problemsolving creatively. Therefore, the concept of science needs to be a significant part of the child's learning process as an effort to optimize children's understanding. Learning science is an activity that requires the classification of scientific investigations and processing. At the early childhood level, these two classifications are realized through meaningful play activities and daily 
experiences. Which is scientific according to the level of understanding and development of children.

\section{Method}

This research is a literature review research from various sources relevant to the topic of science learning concepts in early childhood. The literature is relevant to the theme obtained from several sources such as research gate, google scholar, and books. The technique of conducting a review done by looking for similarities in several kinds of literature and concluding. Data or information analysis done in three steps. Starting with: (1) searching the literature following the topic, (2) finding the main idea of each article, (3) combining the main idea into one complete conclusion on the problem according to the topic.

\section{Results and Discussion}

\subsection{Teacher competence in science learning}

Teachers have a responsibility to prepare learning programs that include the selection of strategies, materials, infrastructure for learners under the abilities and children development. However, in previous research, it was found that not a few teachers feel less mastery of the material covered and how to organize the right activities, making it difficult in teaching science to children. Resulting in the teachers rarely teach science to the children [4]. Which supported by Barenthien's research that pedagogical competence alone is not enough but needs to be accompanied by mastery of science concepts that include materials and diverse teaching strategies to support the basic understanding of children [5]. In line with this, Akman's research suggested that the teacher's positive attitude and support towards children is also a competency that teachers need to hone to adequate more understanding and build a child's positive attitude [6]. Including mastering the right language according to the content of the learning material so can positively impact learning [7]. Regarding these Saçkes findings on teacher competence, found that teacher participation in training related to science learning (program preparation, strategy, materials) is one way to improve teacher competence. This training also affects how often science being teach in the classroom [8].

\subsection{Basic concepts of early childhood science}

Niklas Pramling, in his books, suggests that before thinking about how children learn science, we need to see first how the children think. We should also learn to understand how children construct their knowledge. This process is inseparable from the important role of the teacher, surrounding environment, children's social [9]. Exploration by children indirectly builds knowledge and brings children closer to science learning related to living things, natural events, and technology [10]. Children construct knowledge through exploration that can develop children's motivation to learn and do science activities, as well as deduce things using their language. Start from reading books and questioning the content of books to playing games that contain elements of science [11][12]. In line with this, Trundle's research stated that early childhood science learning has a cycle of "Play-Exploration-Discussion". Which is: 1) Play, 
children are trained to pay attention, question, wonder at new things. 2) Exploration, including predicting, observing, collecting data/information. 3) Discussions, in the form of a series of reflections, knowledge formation, explanations, sharing info, making new questions, concluded [13].

\subsection{Early childhood science learning process}

Children who are used to being trained and have good primary science skills can remember and understand a learning topic better [14]. Kiraz, in his research, states that science learning needs to be given with fun, doing it yourself, finding out for themselves, using their senses. These allow children to develop their thinking skills directly and are not limited to informationonly giving by teachers [15][16]. The process of science learning based on studies conducted by Dejonckheere takes place through several stages include, 1) imitation, where the child tries to imitate what exemplified, 2) exploration and experimentation [17]. Further stated that children's independent activities could improve more of their science skills. This approach allows children to conduct freely observe, integrated activities, systemic new knowledge with daily life suitable with the age, characteristics, and child development [18]. Utami's findings associated with the science learning process state that every exploration, experiment, problemsolving activity, is closely be related to language development. The child learns to communicate associated with is seen, obtained, discovered, and resolved [19]. Therefore, teachers need to plan effective science learning strategies to both introduce science concepts and developing children's literacy [20]. Utilizing science-themed books provides children the chance to improve science literacy skills in different and more challenging ways for children [21].

\subsection{Early childhood science learning program}

Differences in children's understanding and knowledge become one of the challenges for children's learning, especially in managing and solving conflicts during the learning process [22]. Integrated learning activities aim to create more enticing learning activities as well as rich in content. For example, the integration between science and art, where children taught not only the ability to think scientifically but also the aesthetics of art simultaneously [23]. González study stated that involving children in science activities presents challenges for children [24]. In line with this, Macdonald state that children grow up to be competent individuals when allowed to develop ideas and expectations according to their abilities [25].

Another challenge faced is changing the paradigm of the teacher center into the student center by providing opportunities for children to develop scientific experiences and invite children to participate more actively in learning activities. The development of meaningful playbased learning programs, provide varied activities, exchanging information between teachers and learners is one of the efforts to build new science knowledge together [26][27]. The child has been possessed curiosity and acquisition of factual knowledge from the nearest environment. It becomes one of the most effective learning programs in developing children's scientific thinking skills, including the ability to understand and solve existing problems [28][29]. Support this Zinsser, research stated that child-centered activities develop the confidence, social skill, motor, and also adventurous spirit of children [30]. By experiences problems that are close to the child's daily life, they effectively carried out acquiring knowledge concept from factual to abstract. 


\section{Conclusion}

Science learning is a process of obtaining knowledge that takes place through direct interaction among individuals and the environment that aims to find problem-solving creatively. Teacher competence can be improved through science learning training. The training is focused on mastering the scope, material, and strategies of science learning. Every child gaining and processes knowledge by collecting information through personal experience. The science learning process includes providing various activities and media. Including strategy selection, observation, classification, communicating the process and results of activities. Early Childhood Science Learning Program, integrated with material selection and learning activities planning which, fun, meaningful, accommodating the abilities and needs of children.

\section{References}

[1] C. Campbell and W. Jobling, Science in early childhood. Cambridge University Press, 2012.

[2] L. D. Wood, "Viewpoint holding on to play: Reflecting on experiences as a playful K-3 teacher," YC Young Child., vol. 69, no. 2, pp. 48-56, 2014.

[3] L. Turja, M. Endepohls-Ulpe, and M. Chatoney, "A conceptual framework for developing the curriculum and delivery of technology education in early childhood," Int. J. Technol. Des. Educ., vol. 19, no. 4, pp. 353-365, 2009, doi: 10.1007/s10798-009-9093-9.

[4] A. Ibrahim, "Teachers' views about teaching science in preschool," asian Acad. Res. J. Multidiscip., vol. 1, no. April 2015, pp. 431-449, 2016.

[5] J. Barenthien, M. A. Lindner, T. Ziegler, and M. Steffensky, "Exploring preschool teachers' sciencespecific knowledge,” Early Years, vol. 5146, pp. 1-16, 2018, doi: 10.1080/09575146.2018.1443321.

[6] B. Akman, E. Alabay, and P. Aksoy, "A Study on the Effects of Teacher Attitudes on Children 's Beliefs about Science Scanned by TapScanner," 2010, no. April.

[7] C. J. Simonds, Communication for the classroom teacher. 2014.

[8] M. Saçkes, "How often do early childhood teachers teach science concepts? Determinants of the frequency of science teaching in kindergarten," Eur. Early Child. Educ. Res. J., vol. 22, no. 2, pp. 169-184, 2014, doi: 10.1080/1350293X.2012.704305.

[9] M. Niklasspramling, Cultural Studies of Science Education 11 A Cultural-Historical Study of Children Learning Science Foregrounding AA ective Imagination in Play-based Settings. springer, 2015.

[10] K. C. Trundle and M. Saçkes, Research in early childhood science education. springer, 2015.

[11] M. Saçkes, K. C. Trundle, and R. L. Bell, "Science Learning Experiences in Kindergarten and Children's Growth in Science Performance in Elementary Grades Anaokulunda Sağlanan Bilim Öğrenme Deneyimlerinin Çocukların İlköğretim Fen Bilgisi Derslerindeki Performanslarına Etkisi AND CHILDREN'S GRO,” Educ. Sci., vol. 38, no. 167, pp. 114-127, 2013.

[12] M. Saçkes, K. C. Trundle, and M. M. C. Smith, Scientific Concepts during Childhood, Development of, Second Edi., vol. 21, no. 1994. Elsevier, 2015.

[13] K. C. Trundle, K. Mollohan, and M. M. Smith, "Plants, Alike and Different.," Sci. Child., vol. 50, no. 6, pp. 52-57, 2013.

[14] J. P. Byrnes, D. Miller-Cotto, and A. H. Wang, "Children as mediators of their own cognitive development: The case of learning science in kindergarten and first grade," J. Cogn. Dev., vol. 19, no. 3, pp. 248-277, 2018, doi: 10.1080/15248372.2018.1470975.

[15] A. Kiraz and H. Siddık, "An Analysis of Science Activities in Pre-School Education Programmes in Northern Cyprus and Turkey / Kuzey Kıbrıs ve Türkiye Okul Öncesi Eğitim Programlarında Yer Alan Fen Etkinliklerinin Analizi," J. Hist. Cult. Art Res., vol. 7, no. 3, p. 18, 2018, doi: 10.7596/taksad.v7i3.1497. 
[16] D. M. Early et al., "How do pre-kindergarteners spend their time? Gender, ethnicity, and income as predictors of experiences in pre-kindergarten classrooms," Early Child. Res. Q., vol. 25, no. 2, pp. 177-193, 2010, doi: 10.1016/j.ecresq.2009.10.003.

[17] P. J. N. Dejonckheere, N. De Wit, K. Van de Keere, and S. Vervaet, "Exploring the classroom: Teaching science in early childhood,” Int. Electron. J. Elem. Educ., vol. 8, no. 4, pp. 537-558, 2016, doi: 10.12973/eu-jer.5.3.149.

[18] A. Karademir, A. Kartal, and C. Türk, "Science Education Activities in Turkey: A Qualitative Comparison Study in Preschool Classrooms," Early Child. Educ. J., vol. 48, no. 3, pp. 285-304, 2020, doi: 10.1007/s10643-019-00981-1.

[19] B. Utami, S. Saputro, Ashadi, and M. Masykuri, "Scientific literacy in science lesson," Pros. ICTTE FKIP UNS 2015, vol. 1, no. 1, pp. 125-133, 2016.

[20] M. Saçkes, K. C. Trundle, R. L. Bell, and A. A. O'Connell, “The influence of early science experience in kindergarten on children's immediate and later science achievement: Evidence from the Early Childhood Longitudinal Study," J. Res. Sci. Teach., vol. 48, no. 2, pp. 217-235, 2011, doi: 10.1002/tea.20395.

[21] M. Sackes, K. C. Trundle, and L. M. Flevares, "Using children's literature to teach standard-based science concepts in early years," Early Child. Educ. J., vol. 36, no. 5, pp. 415-422, 2009, doi: 10.1007/s10643-009-0304-5.

[22] I. C. T. Education, "Fragkiadaki , G . ( 2020 ). Conflicts during Science Concept Formation in Early Conflicts during Science concept formation in early childhood : barriers or turning points ?," 2020, vol. 14 , no. January.

[23] K. Green, K. C. Trundle, and M. Shaheen, "Integrating the Arts into Science Teaching and Learning: a Literature Review," J. Learn. through Arts A Res. J. Arts Integr. Sch. Communities, vol. 14, no. 1, 2019, doi: 10.21977/d914140829.

[24] S. A. González, R. Godoy, and P. Veas, "Science and Technology Congress for Preschoolers as a strategy for the initiation of science," Early Child Dev. Care, vol. 190, no. 4, pp. 594-614, 2020, doi: $10.1080 / 03004430.2018 .1485672$.

[25] A. Macdonald, Investigating Mathematics, Science. Oxford University Press, 2015.

[26] M. Saçkes, K. C. Trundle, and M. Shaheen, "The Effect of Balanced Learning ${ }^{\circledR}$ Curriculum on Young Children's Learning of Science,” Early Child. Educ. J., vol. 48, no. 3, pp. 305-312, 2020, doi: 10.1007/s10643-019-00985-x.

[27] O. Méndez, "Neoliberalism and Equity: Chilean Society Analyzed from the Student's Perspective," J. Educ. Hum. Dev., vol. 4, no. 2(1), pp. 171--186, 2015, doi: 10.15640/jehd.v4n2.

[28] H. Z. Inan, K. C. Trundle, and R. Kantor, "Understanding natural sciences education in a Reggio Emilia-inspired preschool,” J. Res. Sci. Teach., vol. 47, no. 10, pp. 1186-1208, 2010, doi: 10.1002/tea.20375.

[29] L. French, K. Conezio, and M. Boynton, "Using Science as the Hub of an Integrated Early Childhood Curriculum: The ScienceStart! Curriculum," Issues Early Child. Educ. Curriculum, Teach. Educ. Dissem. Inf., no. November, pp. 5-7, 2000.

[30] K. M. Zinsser, C. G. Christensen, and A. G. Carlson, Both together: Social-emotional learning and cognition promote academic achievement in early childhood classrooms. Nova publishers New York, 2015 . 